\title{
Genetic Regulation of Isocitrate Lyase Activity in Aspergillus nidulans
}

\author{
By W. MCCULLOUGH*† AND C. F. ROBERTS \\ Department of Genetics, University of Leicester, \\ University Road, Leicester LE1 7 RH
}

(Received 6 July 1979; revised 3 December 1979)

\begin{abstract}
The formation of the glyoxylate cycle enzymes isocitrate lyase and malate synthase is strongly regulated in Aspergillus nidulans and the enzymes are induced at high levels in mycelium grown on acetate and found at low levels in mycelium grown on hexose. A search was made for constitutive mutants forming the enzymes when grown on hexose by the use of a pyruvate carboxylaseless ( $p y c A)$ strain. This strain does not grow on hexose since it requires a source of $\mathrm{C}_{4}$ tricarboxylic acid cycle intermediates and it was hoped that among revertants selected for growth on hexose some may effect $\mathrm{C}_{4}$ synthesis by the constitutive formation of the glyoxylate cycle enzymes.
\end{abstract}

Four constitutive strains were isolated. Three had no pyruvate carboxylase activity and each was found to contain two new mutations: a suppressor mutation $s u^{+}$of the pyruvate carboxylase lesion, and a mutation $\mathrm{icl}^{\mathrm{c}}$ which caused low constitutive isocitrate lyase activity. The greater activities in the constitutive strains were due to interactions between the $\mathrm{icl}^{\mathrm{c}}$ and the $s u^{+}$and $p y c A$ mutations.

The four low-level constitutive mutations $i c l^{\mathbf{c}}$ defined two genes affecting isocitrate lyase formation. Recessive mutations in $i^{c}{ }^{c} A$ (linkage group IV; three alleles) caused 10 -fold increased activities in sucrose-grown mycelium, as did a semi-dominant mutation in $i c l c B$ (linkage group I). The $i \mathrm{cl}^{\mathrm{c}}$ genes are not linked to $a c u D$ (structural gene for isocitrate lyase) and did not detectably affect the formation of either malate synthase or acetyl-CoA synthase, the structural gene $(a c u A)$ for which is tightly linked to $a c u D$. There was a synergistic interaction in the double mutant $i c{ }^{\mathbf{c}} A 1 ; i c c^{\mathbf{c}} B 1$. Two alternative interpretations of the $i c l^{\mathrm{c}}$ genes remain open: one is a model for genetic regulation with negative ( $i c l^{c} A$ gene product) and positive ( $\mathrm{icl}^{\mathrm{c} B}$ gene product) elements; the other is endogenous induction due to the accumulation of metabolites resulting from the unidentified metabolic lesions. We did not find any ${ }^{c} c^{\mathbf{c}} B$ mutations uninducible for isocitrate lyase amongst acetate non-utilizing mutants.

A fifth isocitrate lyase constitutive mutant was isolated in the wild-type strain. The mutant contained another recessive mutation $(A 4)$ in the $i c l c A$ gene.

The high constitutive isocitrate lyase activities in $\mathrm{icl}^{\mathrm{c}} \mathrm{Al} ; \mathrm{icl}^{\mathrm{C} B I}$ double mutants did not provide replacement of the $\mathrm{C}_{4}$ requirement in a pyruvate carboxylaseless strain since the triple mutant $p y c A 3 ; i c l^{c} A 1 ; i c l c B 1$ did not grow on sucrose. Revertants of this strain selected for growth on sucrose again contained suppressor mutations su+ of the $p y c A$ lesion and the high constitutive activities for malate synthase decreased as known mutant genes were replaced. The nature of the suppressor gene $s u^{+}$function(s) providing an alternative source of $\mathrm{C}_{4}$ intermediates for growth is not known.

† Present address: School of Life Sciences, Ulster Polytechnic, Jordanstown, Co. Antrim, Northern Ireland. 


\section{INTRODUCTION}

The enzymes of the anaplerotic glyoxylate cycle are formed in many micro-organisms grown on $\mathrm{C}_{2}$ compounds such as acetate, and effect net synthesis of $\mathrm{C}_{4}$ organic acid intermediates of the tricarboxylic acid cycle (Kornberg, 1966a). In Aspergillus nidulans the essential role of the glyoxylate cycle enzymes isocitrate lyase and malate synthase in acetate metabolism was confirmed by the finding that mutants which lack either enzyme activity did not grow on acetate as sole carbon source (Armitt et al., 1976).

In Escherichia coli the structural genes for isocitrate lyase and the acetate-induced malate synthase A (Falmange et al., 1965) constitute an operon the expression of which is controlled by a closely linked regulatory gene (Brice \& Kornberg, 1968), possibly in response to the intracellular concentration of phosphoenolpyruvate (Kornberg, 1966b). Recessive mutations in the regulatory gene lead to the constitutive expression of the operon. On the other hand, in $A$. nidulans the two structural genes are unlinked and show strong induction by growth in the presence of acetate, probably in response to the intracellular concentration of acetylcoenzyme A (Armitt et al., 1976).

We have sought to study the genetic regulation of the glyoxylate cycle enzymes isocitrate lyase and malate synthase in $A$. nidulans by the isolation of constitutive mutants which form the enzymes when grown in the absence of acetate. For this purpose we have used pyruvate carboxylaseless ( $p y c A$ ) mutants which cannot grow on hexose unless supplied with a source of $C_{4}$ tricarboxylic acid cycle intermediates (Skinner \& Armitt, 1972). Revertants of pycA selected for growth on hexose were screened for the possibility that some might bypass the pyruvate carboxylase lesion and effect net $C_{4}$ synthesis by the constitutive formation of the glyoxylate cycle enzymes. Vanderwinkel et al. (1963) recovered such constitutive mutants in $E$. coli amongst revertants of phospoenolpyruvate carboxylaseless mutants.

\section{METHODS}

Organisms. The strains used were from the Glasgow stock of Aspergillus nidulans (Pontecorvo et al., 1953). The strains with wild-type characteristics for carbon source utilization were R21 (pabaA1 yA2) and R153 ( $x \cdot A 3 ;$ pyro A4). Two 'master strains' were used to allocate mutant alleles to linkage groups, FGSC 105 (biAl; AcrAl wA3; phenA2; pyroA4; lysB5; sB3; nicB8; coA1) and FGSC 480 (proA1 $y^{\circ} A 91$; IodA1; phenA2; methG1; nicA2; sbA3; malA1; riboB2). A recent listing of mutant allele characters is given by Clutterbuck (1974).

The pyruvate carboxylase deficient (pycA3) mutant was isolated in this laboratory (Skinner \& Armitt, 1972) as were the acetate non-utilizing acu mutants (Armitt et al., 1976). Double mutant strains combining both pycA3 and certain acu markers were constructed by meiotic recombination. In the case of pycA3; acuM301 (the second lesion being in malic enzyme) the double mutant grows well on a mixture of sucrose $(0.02 \mathrm{M})$ with acetate $(0.10 \mathrm{M})$. The pycA3; acuA204 double mutant cannot utilize acetate due to the lesion in acetyl-CoA synthase $(a c u A)$; it grows well on a mixture of $0.04 \mathrm{M}$-L-proline, as a source of $\mathrm{C}_{4}$ tricarboxylic acid cycle intermediates, and $0.04 \mathrm{M}$-glycerol, as a glycolytic carbon source not repressing proline utilization. All strains used were in the R21 (pabaA1 yA2) or R153 (wA3; pyroA4) genotypes.

Most of the media and experimental procedures were described by Armitt et al. (1976). Revised or new methods used in the present work are given below.

Mutagenesis. Suspensions of conidia were treated with $N$-methyl- $N^{\prime}$-nitro- $N$-nitrosoguanidine following the method of Alderson \& Hartley (1969) as modified by Waldron \& Roberts (1974). Survival was of the order of $1 \%$. In certain experiments suspensions of conidia were exposed to ultraviolet light such that about $30 \%$ survived.

A qualitative test for isocitrate lyase activity in whole mycelium. A method to permit the rapid screening of large numbers of strains for the presence of isocitrate lyase activity was developed from the frozen cell assay described by Syrett $e t$ al. (1963). The principle is that whole mycelium is rendered permeable to substrate and reagents by freezing and thawing. The enzyme cleaves isocitric acid to release glyoxylic acid which is trapped with phenylhydrazine and the derivative is oxidized to a characteristic cherry-red formazan in acid solution. The method was applied to mycelium grown either in liquid culture or on solid medium. The technique was monitored by using mycelium grown with acetate to induce isocitrate lyase or grown 
with hexose when enzyme activity is very low. We also verified the method in several experiments in which strains were both classified by the qualitative test and their isocitrate lyase activities were determined by assay.

Liquid culture: Mycelium was grown overnight in $20 \mathrm{ml}$ minimal medium in $100 \mathrm{ml}$ conical flasks incubated at $37{ }^{\circ} \mathrm{C}$ on a gyrotary shaker operating at $80 \mathrm{rev}$. $\mathrm{min}^{-1}$. Mycelium was harvested on a filter apparatus accepting up to six separate samples and washed with distilled water and $0.05 \mathrm{M}$-sodium phosphate buffer $\mathrm{pH} \mathrm{7.0.} \mathrm{The} \mathrm{whole} \mathrm{mycelial} \mathrm{pad} \mathrm{was} \mathrm{resuspended} \mathrm{in} \mathrm{a} \mathrm{test-tube} \mathrm{with} 2.0 \mathrm{ml}$ of the same buffer and frozen for at least $15 \mathrm{~min}$ in a dry ice/methanol mixture or for $1 \mathrm{~h}$ in a deep-freeze at $-80^{\circ} \mathrm{C}$. The samples were thawed at $4{ }^{\circ} \mathrm{C}$, taking about $3 \mathrm{~h}$ to melt fully. The reaction mixture contained 4 vol. $0.1 \mathrm{M}-\mathrm{MgCl}_{2}$, 1 vol. 0.1 M-EDTA pH 6.7 and 1 vol. 0.1 M-DL-isocitric acid. Each sample was tested as follows. The reaction was started by adding $0.3 \mathrm{ml}$ of the reaction mixture and then incubated at $37^{\circ} \mathrm{C}$ for $30 \mathrm{~min}$. It was stopped by adding $0.4 \mathrm{ml} 20 \%(\mathrm{v} / \mathrm{v})$ trichloroacetic acid followed immediately by mixing with $1.0 \mathrm{ml} 1 \%(\mathrm{w} / \mathrm{v})$ freshly prepared phenylhydrazine. $\mathrm{HCl}$. After further incubation at $37{ }^{\circ} \mathrm{C}$ for $45 \mathrm{~min}, 1.0 \mathrm{ml}$ concentrated $\mathrm{HCl}$ was added and mixed, and then $1.0 \mathrm{ml} 1 \%(\mathrm{w} / \mathrm{v})$ freshly prepared potassium ferricyanide was added with immediate mixing. The characteristic cherry-red formazan developed over $15 \mathrm{~min}$ and indicated the presence of glyoxylic acid released from isocitric acid by isocitrate lyase. The intensity of the colour provided an indication of the amount of enzyme activity when similar amounts of mycelium were used.

Solid media: Colonies were grown at $37^{\circ} \mathrm{C}$ on minimal medium solidified with $0.5 \%(\mathrm{w} / \mathrm{v})$ agar and tested before heavy conidiation occurred. The reaction mixture contained $25 \mathrm{vol} .0 .1 \mathrm{M}$-sodium phosphate buffer $\mathrm{pH} 7 \cdot 0,5$ vol. $0.1 \mathrm{M}-\mathrm{MgCl}_{2}, 1$ vol. 0.1 M-EDTA pH 6.7 and 3 vol. 0.1 M-DL-isocitric acid. The test was done using immunological 'microtitre' trays each consisting of 96 individual wide-aperture wells. Each well was charged with 2 drops (about $0.1 \mathrm{ml}$ ) of reaction mixture delivered with a Pasteur pipette. A small block of agar ( 2 to $3 \mathrm{~mm}^{3}$ ) containing non-conidiating mycelium was cut from the periphery of each colony tested and the blocks were transferred to separate wells in the tray. The samples were frozen at $-80^{\circ} \mathrm{C}$ overnight and then thawed slowly, first for $1.5 \mathrm{~h}$ at $-20^{\circ} \mathrm{C}$ and then for a further 2 to $3 \mathrm{~h}$ at $4{ }^{\circ} \mathrm{C}$ until fully meited. The samples were then incubated for 2 to $3 \mathrm{~h}$ at $37^{\circ} \mathrm{C}$, one drop (about $0.05 \mathrm{ml}$ ) of freshly prepared phenylhydrazine. $\mathrm{HCl}$ was added to each well and incubation was continued for a further 20 to $30 \mathrm{~min}$. Finally, 1 drop each of concentrated $\mathrm{HCl}$ and freshly prepared potassium ferricyanide were added to each well. The characteristic cherry-red formazan indicating isocitrate lyase activity developed within $15 \mathrm{~min}$. Trays could be stored for up to 1 week at $-20^{\circ} \mathrm{C}$ without loss of colour.

The tests were monitored by including induced and non-induced mycelium. With standard samples of mycelium, the intensity of colour indicated different levels of enzyme activity. The sensitivity of the test could also be adjusted to detect different enzyme activities by varying the substrate concentration and incubation time. The presence of certain compounds added to the medium as growth supplement, for example, thiosulphate, or of higher concentrations of agar may interfere with the test.

Enzyme assays. The assay procedures were the same as described previously (Armitt et al., 1976).

Pyruvate carboxylase (EC 6.4.1.1) was measured on a Pye Unicam SP800 recording spectrophotometer using the coupled assay with malate dehydrogenase described by Miller \& Atkinson (1972). Mycelium was broken by sonication (MSE 150 W ultrasonic disintegration) in ice-cold buffer for three $10 \mathrm{~s}$ periods separated by $30 \mathrm{~s}$ intervals. The buffer system was $0.02 \mathrm{M}-\mathrm{Tris} / \mathrm{HCl} \mathrm{pH} 7.5$ containing $0.002 \mathrm{M}-\mathrm{MgCl}_{2}$ and 0.001 $M$-EDTA. The broken mycelium was centrifuged for $1 \mathrm{~h}$ at $100000 \mathrm{~g}$ in a Beckman ultracentrifuge and samples were carefully withdrawn from the top of the tube for assay. The assay was done at $37^{\circ} \mathrm{C}$. The reaction mixture contained: $0.4 \mathrm{M}-\mathrm{Tr}$ s $/ \mathrm{HCl} \mathrm{pH} 7.5,0.25 \mathrm{ml} ; 0.05 \mathrm{M}-\mathrm{MgCl}_{2}, 0.1 \mathrm{ml} ; 0.04 \mathrm{M}-\mathrm{ATP}$ pH 7.0, $0.1 \mathrm{ml} ; 0.4 \mathrm{M}-\mathrm{KCl}, 0.1 \mathrm{ml} ; 0.1 \mathrm{M}$-sodium pyruvate pH 7.0, $0.1 \mathrm{ml} ; 0.12 \mathrm{M}-\mathrm{KHCO}_{2}, 0.1 \mathrm{ml} ;$ malate dehydrogenase, 5 to 10 units; NADH $\left(1 \mathrm{mg} \mathrm{ml}^{-1}\right), 0.1 \mathrm{ml}$; cell-free extract and water to $1.0 \mathrm{ml}$. The $\mathrm{KHCO}_{8}$ and NADH solutions were always freshly prepared. The reaction was started by the addition of bicarbonate to the sample cuvette.

\section{RESULTS}

\section{Selection of pycA revertants and screening for constitutive isocitrate lyase activity}

Suspensions of conidia of pycA strains, which lack pyruvate carboxylase activity, were treated with $N$-methyl- $N^{\prime}$-nitro- $N$-nitrosoguanidine and revertants were selected by growth on sucrose minimal medium plates. Two distinct types of revertant were recovered in many different experiments. The first type formed colonies after 2 to $\mathbf{3} \mathrm{d}$ incubation, grew vigorously on sucrose and conidiated well. The second type grew slowly and formed poorly conidiating colonies only after 3 to $6 \mathrm{~d}$ incubation.

The first type of revertant appeared to have arisen by back mutation at the $p y c A$ locus, 
for the strains had readily detectable pyruvate carboxylase activity and all the progeny in a cross to wild-type grew normally on sucrose. A minority of revertants - overall some $20 \%$ of strains examined - fell into this category. These strains also grew well on sucrose in liquid medium and had very low isocitrate lyase activity.

The second type of revertant was remarkable in a number of ways, not least for the high frequency of recovery. The strains did not contain detectable pyruvate carboxylase activity when grown on acetate, and the presence of the $p y c A$ mutation was confirmed by crosses to wild-type in which about a quarter of the progeny were unable to grow on sucrose. A further quarter of the progeny grew slowly like the revertant and the remaining progeny grew well on sucrose. All the progeny grew well on acetate minimal medium on which the ascospores had been plated. It is therefore evident that such revertant strains contain a suppressor mutation $\mathrm{su}^{+}$of the pycA lesion, and four classes of progeny are predicted on the basis of two mutant genes, pycA and su+, segregating in a cross to wild-type. (The original, or wild-type, non-effective allele at the suppressor locus is designated $s u^{-}$, and the suppressing mutant allele $s u^{+}$). The validity of this model was confirmed by showing that among the progeny growing well on sucrose, some contained the $s u^{+}$mutation and produced the revertant phenotype when combined with the pycA mutation. While there was some difference in the growth of the $p y c A^{+}, s u^{-}$and $p y c A^{+}, s u^{+}$progeny when stab-inoculated on sucrose plates, they could not be reliably separated. However, it was found that the two classes could be differentiated if conidial suspensions were plated on sucrose minimal medium to produce isolated colonies. Wild-type strains produced dense colonies with good conidiation while $p y c A^{+}, s u^{+}$strains produced colonies in which the amount of mycelium and degree of conidiation was perceptibly decreased.

A further remarkable property of this second type of revertant was that although selected for growth on sucrose minimal medium plates many did not grow when tested in liquid sucrose minimal medium. This difference could result from the utilization of carbon sources in agar, and so further selection experiments were done in pycA strains combined with acu (acetate non-utilizing) mutations which prevent growth of $A$. nidulans on agar as carbon source (Payton et al., 1976).

The qualitative test for isocitrate lyase activity was used to screen revertants for constitutive enzyme formation in what was effectively a double selection programme. The revertant colonies were subcultured to complete medium sucrose slants, and conidia from those strains which grew reasonably well were inoculated into small volume cultures $(25 \mathrm{ml}$ in a $150 \mathrm{ml}$ conical fiask) of liquid minimal medium sucrose and incubated on a platform shaker. Those cultures which grew within $48 \mathrm{~h}$ were harvested by filtration and screened for the presence of isocitrate lyase activity. Four constitutive strains, defined by their capacity to form isocitrate lyase when grown in sucrose liquid medium, were recovered by this procedure. Three were isolated in pycA3; acu strains (Table 1) from among some 200 revertants selected on sucrose plates, about half of which grew in sucrose liquid medium.

The fourth constitutive strain ( $p y c A 3 \mathrm{r} 37$, Table 1) was obtained as a slow-growing revertant of a pyruvate carboxylase-deficient strain selected on solid medium containing sucrose as carbon source in the presence of $20 \mathrm{~mm}$-propionate. Propionate is not a carbon source for the growth of $\boldsymbol{A}$. nidulans but causes considerable induction of isocitrate lyase (unpublished observation) and was included in the selective medium in an unsuccessful attempt to isolate malate synthase constitutive strains. However, the revertant grew in the same way on sucrose medium in the absence of propionate and was subsequently found to form isocitrate lyase constitutively when grown in sucrose liquid medium. It is not known whether the presence of propionate was necessary for the isolation of this constitutive strain.

The activity of isocitrate lyase in acetate-grown mycelium of wild-type strains is between 25 and 50 units $\left[\mu \mathrm{mol}\right.$ product $\left.\mathrm{h}^{-1}(\mathrm{mg} \text { protein })^{-1}\right]$ while that in mycelium induced by growth on a mixture of sucrose with acetate is between 10 and 15 units. Very low activities $\leqslant 0 \cdot 1$ 


\section{Table 1. Isocitrate lyase constitutive mutants in A. nidulans}

Strains were grown under the conditions indicated, with carbon sources supplied as 0.02 M-sucrose and 0-10 M-acetate, and isocitrate lyase activities were assayed in cell-free extracts (see Methods). Pyruvate carboxylase activities were determined in the strains grown in the same way on other occasions. Specific activities are expressed as $\mu \mathrm{mol}_{\text {product }} \mathbf{h}^{-1}$ (mg protein) ${ }^{-1}$.

\begin{tabular}{|c|c|c|c|c|}
\hline \multirow[b]{2}{*}{ Strain } & \multicolumn{2}{|c|}{ Growth conditions } & \multicolumn{2}{|c|}{ Specific activities } \\
\hline & Carbon source & $\begin{array}{l}\text { Incubation } \\
\text { time (h) }\end{array}$ & $\begin{array}{l}\text { Isocitrate } \\
\text { lyase }\end{array}$ & $\begin{array}{c}\text { Pyruvate } \\
\text { carboxylase }\end{array}$ \\
\hline R21 (wild-type) & $\begin{array}{l}\text { Acetate } \\
\text { Sucrose + acetate } \\
\text { Sucrose }\end{array}$ & $\begin{array}{l}24 \\
18 \\
18\end{array}$ & $\begin{array}{c}(40) * \\
7 \cdot 1 \\
0 \cdot 1\end{array}$ & $\begin{array}{l}4.8 \\
6 \cdot 0\end{array}$ \\
\hline русA3; асиМ301 r25 & $\begin{array}{l}\text { Sucrose } \\
\text { Sucrose }\end{array}$ & $\begin{array}{l}18 \\
25\end{array}$ & $\begin{array}{l}6 \cdot 4 \\
5 \cdot 5\end{array}$ & $\begin{array}{l}0 \\
0\end{array}$ \\
\hline R21 (wild-type) & $\begin{array}{l}\text { Sucrose + acetate } \\
\text { Sucrose }\end{array}$ & $\begin{array}{l}18 \\
18\end{array}$ & $\begin{array}{r}11.4 \\
0.2\end{array}$ & $4 \cdot 7 \dagger$ \\
\hline русA3; асиМ301 r112 & $\begin{array}{l}\text { Sucrose } \\
\text { Sucrose }\end{array}$ & $\begin{array}{l}12 \\
18\end{array}$ & $\begin{array}{l}1.6 \\
1.6\end{array}$ & $0.6 \dagger$ \\
\hline pycA3; acuA204 r60 & Sucrose & 26 & $5 \cdot 2$ & 0 \\
\hline pycA3 r37 & Sucrose & 48 & $12 \cdot 0$ & 0 \\
\hline $\mathrm{R} 21 \mathrm{icl}^{\mathrm{e}} 2301$ & Sucrose & 18 & 6.6 & Not determined \\
\hline
\end{tabular}

units are found in sucrose-grown mycelium. The constitutive strains therefore have isocitrate lyase activities from 8 to 60 times greater than the wild-type activity during growth on sucrose (Table 1). Strain pycA3 r37 stands apart in having an activity comparable with that of wild-type induced by growth on sucrose with acetate.

Three of the revertants lacked any detectable pyruvate carboxylase activity (Table 1) and thus presumably still contained the pycA3 mutation. The genetic composition of the constitutive strains was established by the analysis of a series of crosses to wild-type. This analysis also suggested an interpretation of the physiological basis on which the constitutive strains were recovered.

\section{Genetic analysis of the isocitrate lyase constitutive strain pycA3; acuM 301 r25}

The original strain required both acetate and sucrose for growth due to the pycA (pyruvate carboxylase) and acuM (malic enzyme) lesions. The revertant grew on sucrose alone, i.e. it had lost the requirement for acetate as a source of $\mathrm{C}_{4}$ tricarboxylic acid cycle intermediates resulting from the $p y c A 3$ lesion. However, it retained the character of the initial strain in not growing on acetate, thus showing the presence of the acuM lesion. Unexpectedly, the revertant grew very poorly on sucrose plus acetate, whereas the original strain grew well.

A cross of the revertant to a wild-type strain (R21) proved complex since the progeny exhibited a range of phenotypes for growth on sucrose or on sucrose plus acetate. However, it eventually emerged that the revertant contained two new mutations in addition to $p y c A 3$ and acuM301. One was a suppressor mutation, su+, of the pycA lesion and the other a mutation, $i c l c$, for constitutive isocitrate lyase formation. The full genotypes of the strains used in the cross are as follows. (The Roman numerals identify the linkage groups).

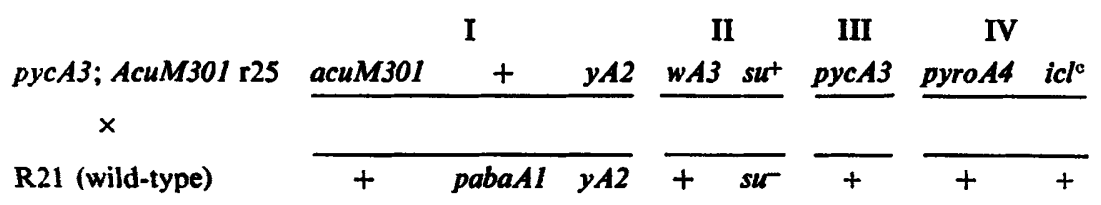




\section{Table 2(a). Characteristics of the progeny from the cross between strain pycA3; acuM301 r25 and wild-type (R21)}

The progeny were first tested for growth on the carbon sources shown by mass (stab) inoculation on plates. Growth on sucrose was scored as NIL for no growth, the pycA3 phenotype, SLOW for poor growth, the phenotype of the revertant strain r25, or GOOD, the wild-type character. On acetate plates progeny were clearly either non-growing, scored-, the acuM mutant phenotype, or wild-type, scored + . Certain progeny grew very poorly on a mixture of sucrose $(0.02 \mathrm{M})$ with acetate $(0.10 \mathrm{M})$ and were scored $(+)$, while the remainder grew normally, scored + . The numbers of progeny in each class are shown at the left of the Table.

A number of progeny from each of the classes were then tested more extensively. Suspensions of conidia were plated at high dilution on sucrose medium to produce isolated colonies, each presumed to arise from a single conidium. Control platings were done on sucrose plus acetate medium and on complete medium with acetate. Some progeny failed to form colonies on the sucrose plates, while others produced 'sparse' colonies in which the density of mycelium and conidiation was diminished. These 'sparse' colonies were clearly distinguishable as being of small diameter (5 to $10 \mathrm{~mm}$ ) or large diameter (15 to $20 \mathrm{~mm}$ ) after $4 \mathrm{~d}$ incubation. The remaining progeny were wild-type, producing large colonies with 'dense' mycelium and heavy conidiation. Those strains growing poorly where mass inoculated into sucrose plus acetate medium also showed poor growth when plated to produce isolated colonies on the same medium. They were shown enclosed within thick lines.

Finally, the constitutive isocitrate lyase activity was measured in representative progeny after growth on sucrose $(0.02 \mathrm{M})$ in liquid culture for $18 \mathrm{~h}$. Specific activities [ $\mu \mathrm{mol}$ product $\mathrm{h}^{-1}\left(\mathrm{mg}^{\circ}\right.$ protein $)^{-1}$ ] are shown by the symbols: $0,\langle 0.3 ; 0,0.6$ to $1.0 ; 0,1.0$ to $3.0 ; \square, 6.0$ to 8.0 . Individual progeny are identified by numbers; for example, 0 1-6 signifies that strain 1-6 had a constitutive isocitrate lyase activity in the range 0.6 to 1.0 units. Progeny which did not grow on sucrose in liquid culture are shown without a symbol.



Ascospores from a single hybrid cleistothecium were plated at a suitable dilution on complete medium with sucrose and acetate. The conidial colour marker $(w A 3 /+)$ segregated $1: 1$ in the progeny as did the nutritional markers pabaAl ++ and pyro $A 4 /+$. Similarly, the marker for inability to utilize acetate $(a c u M 301 /+)$ also segregated 1:1 (Table $2 a)$. When progeny were tested for growth on sucrose the same three classes of progeny were found as described above for segregation of $p y c A$ and an unlinked suppressor $s u^{+}$and it is evident that the revertant strain carries such a mutation. In addition about a quarter of all the progeny grew poorly on sucrose with acetate. All of this class were acetate non-utilizing 
Table 2(b). Genotypes of the progeny from the cross between strain pycA3; acuM301 r25 and wild-type (R21)

The phenotypes of progeny from the cross described in Table $2(a)$ are interpreted on the basis of a genetic model in which strain r25 contains two new mutant genes, su+ (a suppressor of pycA3) and $i c l^{c} A$ (constitutive formation of isocitrate lyase). These genes assort independently of each other and of pyc $A 3$ (pyruvate carboxylase deficiency) and acuM301 (malic enzyme deficiency).



acuM strains and the 1:4 ratio suggests that the second genetic factor determining this phenotype may be the $s u^{+}$mutation.

To test the segregation of isocitrate lyase constitutivity it was necessary to grow progeny capable of sucrose utilization in liquid culture. We were surprised to find that about half of the slow-growing suppressed strains $\left(p y c A ; s u^{+}\right)$did not grow on sucrose in liquid culture although all these strains grew when mass inoculated on sucrose plates (Table 2a). This observation prompted us to test the growth of strains on solid sucrose medium when conidial suspensions were plated to yield isolated colonies each arising from a single conidium. We found that those $p y c A$; su+ progeny which could grow in liquid medium formed small poorly conidiating 'sparse' colonies whereas the others did not grow. More interestingly, when the strains which grew well from mass inoculation on sucrose plates were examined in the same way they also fell into two clearly separated classes. One half yielded 'sparse' colonies, in which the density of mycelium and amount of conidiation was reduced, while the other half grew 'densely' and conidiated heavily, as does the wild-type. These two classes could be $p y c A^{+}$carrying, respectively, the $s u^{+}$or $s u^{-}$(wild-type) alleles. This hypothesis was strengthened by finding that all the 'sparse' colonies which also carry the acuM mutation grew poorly on sucrose plus acetate, whereas the $a c u M$ 'dense' colonies grew normally (Table 2a).

When representative progeny were examined for constitutive isocitrate lyase formation it immediately became clear that constitutivity segregated to one-half of the progeny independently of the other markers in the cross (Table $2 a$ ). We therefore identified an isocitrate lyase constitutive mutation $i c l c$, in addition to the $s u^{+}$mutation. An interesting correlation also emerges between the growth of the $p y c A ; s u^{+}$progeny in sucrose liquid medium and the presence of the $i^{c} l^{\mathbf{c}}$ mutation, suggesting a possible physiological role for the $\mathrm{icl}^{\mathrm{c}}$ mutation in enabling growth of the $\mathrm{r} 25 \mathrm{pycA} ; \mathrm{su}^{+}$strain in liquid culture. If this 
hypothesis is true, the $p y c A ; s u^{+}$progeny which do not grow on sucrose in liquid culture should not contain the $i \mathrm{cl}^{\mathrm{c}}$ mutation.

The genetic model of four mutant genes - pycA, acuM, su+ and iclc - which can account for the phenotypic classes found in the cross is shown in Table $2(b)$. This model has been rigorously examined in a series of test crosses between progeny representative of each class and either $p y c A$ or wild-type strains.

In order to locate the two new mutant alleles $\left(s u^{+}\right.$and $\left.i c l^{\mathrm{c}}\right)$ to linkage groups by mitotic haploidization, heterozygous diploid strains were synthesized between a 'master strain' (R87) and recombinant strains carrying either the $p y c A$; su+ mutations (12-5) or the $\mathrm{icl}^{\mathrm{c}}$ mutation (13-22). The $\mathrm{su}^{+}$mutation was located in linkage group II, confirming the absence of linkage with pycA (group III). The $i^{1} l^{c}$ mutation was located in linkage group IV. The locus is designated $\mathrm{icl}^{\mathbf{c}} \mathrm{A}$ and the mutant allele number $1(\mathrm{icl} \mathbf{c} A l)$. This regulatory locus is therefore not linked to the structural gene for isocitrate lyase $a c u D$ (linkage group $V$ ) or to that for malate synthase $a c u E$ (linkage group I).

\section{Genetic analysis of other isocitrate lyase constitutive strains isolated by reversion of pycA}

Strain $\mathrm{r} 112$ was isolated as a sucrose-utilizing isocitrate lyase constitutive revertant of pycA3; acuM301. The strain differed from $\mathrm{r} 25$ and the other pycA3 revertants in containing detectable amounts of pyruvate carboxylase activity (Table 1). This indicates that reversion had occurred by further mutation within or closely linked to the pycA3 locus, and this was confirmed by finding no sucrose non-utilizing progeny among 300 tested from a cross to wild-type. When the progeny were tested for constitutive isocitrate lyase formation, the character segregated to half of the strains independently of the acuM marker. We therefore identified a second isocitrate lyase constitutive mutation (iclc) which was isolated in an acu $M^{-}$recombinant, shown to be allelic with the $i c l^{c} A I$ mutation in heterozygous diploid strains (Table 3), and designated $i c l \mathbf{c} A 2$.

Strain pycA3; acuA204 contains the $p y c A$ lesion combined with an acetyl-CoA synthase lesion (acuA). The revertant $\mathrm{r} 60$ grew slowly on sucrose and exhibited the acuA lesion. The cross to wild-type showed that the revertant contained both the pycA suppressor mutation $\left(s u^{+}\right)$and an unlinked isocitrate lyase constitutive mutation $(\mathrm{iclc})$. The constitutive mutation was isolated in an otherwise wild-type recombinant, found to be allelic with $\mathrm{iclc}^{\mathrm{c}} \boldsymbol{A I}$ in a heterozygous diploid, and designated $i c / c A 3$.

Strain $\mathrm{r} 37$ was isolated as a revertant pycA3 which formed isocitrate lyase constitutively when grown in liquid culture with sucrose as carbon source. The strain grew very slowly on sucrose plates and, in contrast to the parent strain, also grew slowly on acetate plates. When crossed with wild-type, the character of slow growth on acetate segregated in half of the progeny. In addition about half of the progeny did not grow on sucrose, indicating segregation of the pycA mutation. While this observation suggests that the revertant strain $\mathrm{r} 37$ contains a suppressor mutation (su+) of the pycA lesion, the expectation would then be that one-quarter of the progeny (the $p y c A ; s u^{-}$class) should not utilize sucrose. The exact genetic constitution of the revertant strain remains undefined, especially whether it contains a suppressor mutation different from, and in addition to, that mutation conferring slow growth. Among the progeny growing on sucrose about one-half formed isocitrate lyase constitutively. Moreover, constitutivity segregated to half of the strains exhibiting slow growth, indicating the segregation of an isocitrate lyase constitutive mutation (iclc) independently of other mutant characters. This constitutive mutation was isolated in a recombinant otherwise exhibiting none of the mutant characters segregating in the cross. This recombinant (M279) was used in further analysis of the constitutive mutation.

To allocate the constitutive mutation to its linkage group strain M279 was combined with a tester strain (R87) to yield a heterozygous diploid. Analysis of the diploid by mitotic 
Table 3. Expression of the isocitrate lyase constitutive mutations in diploid strains

Diploid strains were synthesized between haploid strains with the complementary genotypes of strains R21 (pabaAI yA2) and R153 (wA3; pyroA4). The diploids were grown in sucrose (0.02 M) liquid medium for $18 \mathrm{~h}$ before harvesting and assay of isocitrate lyase in cell-free extracts. Specific activities are expressed as $\mu \mathrm{mol}$ glyoxylate formed $\mathbf{h}^{-1}$ (mg protein) ${ }^{-1}$.

\begin{tabular}{|c|c|c|}
\hline \multicolumn{2}{|c|}{ Genotype of diploid } & \multirow{2}{*}{$\begin{array}{l}\text { Specific activity of } \\
\text { isocitrate lyase }\end{array}$} \\
\hline$i c l^{\mathrm{e}} A$ locus & $i c l^{c} B$ locus & \\
\hline$+1+$ & $+/+$ & $0 \cdot 10$ \\
\hline $\begin{array}{l}i c l^{\circ} A 1 /+ \\
i c l^{A} A 4 /+ \\
i c l^{e} A I / i c l^{\circ} A 2 \\
i c l^{\circ} A I / i c l^{\circ} A 4\end{array}$ & $\begin{array}{l}+1+ \\
+1+ \\
+1+ \\
+1+\end{array}$ & $\begin{array}{l}0.05 \\
0.39 \\
1.60 \\
5.80\end{array}$ \\
\hline $\begin{array}{l}+1+ \\
+1+\end{array}$ & $\begin{array}{l}i c l^{\circ} B 1 /+ \\
i c l^{\circ} B 1 / i c l^{e} B 1\end{array}$ & $\begin{array}{l}0.92 \\
2 \cdot 80\end{array}$ \\
\hline $\begin{array}{l}i c l^{\circ} A 1 /+ \\
i c l^{c} A I / i c l^{\circ} A I \\
i c l^{c} A I /+ \\
i c l^{\circ} A I / i c l^{\circ} A I\end{array}$ & $\begin{array}{l}i c l^{\circ} B 1 /+ \\
i c l^{\circ} B 1 /+ \\
i c l^{\circ} B 1 / i c l^{c} B 1 \\
i c l^{\circ} B 1 / i c l^{c} B 1\end{array}$ & $\begin{array}{l}1 \cdot 06 \\
2 \cdot 72 \\
2 \cdot 17 \\
8 \cdot 40\end{array}$ \\
\hline
\end{tabular}

haploidization clearly located the $i c l^{c}$ mutation in linkage group I. Thus, a second locus for regulation of isocitrate lyase formation was revealed. It was designated $i_{c} l^{c} B$ and the mutant allele was numbered $B 1$. Thus, neither the $i c l^{\circ} A$ locus nor the $i c c^{c} B$ locus are on the same linkage group as the structural gene ( $a c u D$, linkage group $V$ ) of the enzyme which they affect.

\section{Direct isolation of isocitrate lyase constitutive mutants in wild-type}

Since the isocitrate lyase constitutive mutations isolated from revertants of $p y c A$ strains did not repair the pyruvate carboxylase lesion, and the acu mutations did not prevent expression of the suppressor $\mathrm{su}^{+}$mutations in growth on solid media, we decided to attempt to isolate constitutive mutants directly in the wild-type.

Altogether, 8000 colonies of R21 and 4200 colonies of R153 surviving mutagenesis were screened; a number of low-level isocitrate lyase constitutive strains were found but not retained for analysis. A single strain (2301) was found which showed a higher constitutive enzyme activity, comparable with those observed in the previous constitutive strains (Table 1). When strain 2301 was crossed with wild-type, high-level constitutivity segregated to half of the progeny. The mutation is recessive to wild-type in the heterozygous diploid (Table 3) and was located in linkage group IV by mitotic haploidization. The 2301 constitutive mutation is allelic with $i c c^{c} A l$ and was designated $i c l c A 4$ (Table 3). The $i c /{ }^{\circ} A 4$ mutation was closely linked to the meth $G$ marker in a meiotic cross (about $2 \%$ recombination) thus mapping the $i{ }^{\mathfrak{c}} A$ locus within linkage group IV.

The constitutive mutations act at the isocitrate lyase structural gene (acuD) locus

Constitutive isocitrate lyase activity was monitored in the progeny of the cross between pycA3; acuM30I; su+; iclc $A 1$ and wild-type both by use of the qualitative test and the spectrophotometric assay. There was excellent correlation between the qualitative tests and the assays. However, it was important to rule out the possibility that we were observing a spurious enzymic activity in the constitutive mutants on another protein rather than a change in the regulation of isocitrate lyase. Analysis of crosses between the acuD mutants and the constitutive mutants showed that in each case the $a c u D$ mutation abolished the constitutive enzyme activity, while the $a c u D^{+}$progeny exhibited segregation of the constitutive character. 


\section{Table 4. Effect of genetic background on the expression of the ${ }^{\mathrm{C}} \mathrm{Cl}^{\mathrm{C}} \mathrm{Al}$ mutation}

Isocitrate lyase activities were measured in cell-free extracts of progeny from the cross between pycA3; acuM301; su+; icl $l^{\circ} \mathrm{Al}$ and wild-type after growth in liquid culture for $18 \mathrm{~h}$ with sucrose $(0.02 \mathrm{M})$ as carbon source. Specific activities are expressed as $\mu \mathrm{mol}$ glyoxylate formed $\mathrm{h}^{-1}(\mathrm{mg}$ protein) ${ }^{-1}$.

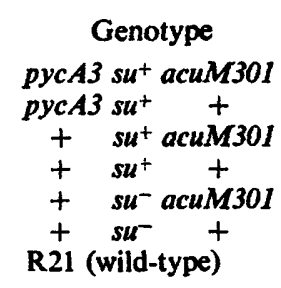

\section{Enzyme activities in the icl $\mathbf{c}$ mutants}

$\begin{array}{cc}\overbrace{i c l^{c} A 1} & i c l^{c} A^{+} \\ 6.23 \pm 1.04 & \\ 7.77 \pm 0.76 & \\ 1.05 \pm 0.49 & 0.14 \pm 0.09 \\ 2.18 \pm 0.38 & 0.17 \pm 0.06 \\ 0.82 \pm 0.09 & 0.17 \pm 0.10 \\ 1.38 \pm 0.06 & 0.15 \pm 0.04 \\ & 0.16 \pm 0.11\end{array}$

Certain aspects of the formation of isocitrate lyase in haploid and in diploid strains were examined together with the possibility that the constitutive mutations affect the formation of other metabolically related enzymes.

Effect of genetic background on the expression of the icl $\mathrm{A}$ mutation. An effect of other identified genes was found when the constitutive isocitrate lyase activities were measured in the different classes of progeny from the cross between pycA3;acuM301; su+; iclc $\mathrm{Al}$ and wild-type (Table 4). The activities were very low in all non-constitutive progeny, while the constitutive activities ranged from 1 to 8 units according to the genotype of the $i \mathrm{cl}^{\mathrm{c}} \mathrm{Al}$ strain. The highest activities were in the $p y c A$; $s u^{+}$progeny and these were comparable with the activity in the original strain (Table 1). Among the $p y c A^{+}$progeny the constitutive activities were about 2 units and the presence of the malic enzyme lesion ( $a c u M$ ) depressed the activity to 1 unit. The high activities in the $p y c A ; s u^{+}$strains may reflect their slow growth rate. It is unlikely that these differences stem from changes in the enzyme's catalytic activity and we take them to reflect the amounts of enzyme produced. Since the $i c l c A l$ mutation is recessive and thus presumably causes a loss of gene function, it is unlikely that the $p y c A$ and $a c u M$ lesions can directly affect the mutant gene's expression. It seems reasonable to suppose that the $p y c A$ and $a c u M$ lesions affect expression of the isocitrate lyase structural gene $\left(a c u D^{+}\right)$ through concentrations of metabolic intermediates. These results illustrate the complexity of regulatory controls affecting the locus.

Synergism between the icl $A$ and $i c l c B$ mutations. Suitable recombinant strains containing only the $i^{c}{ }^{c} A l$ or $i^{c}{ }^{c} B 1$ mutations were crossed and the progeny were examined for constitutive isocitrate lyase activity using the qualitative test. Three classes of progeny occurred; about a quarter of the progeny had very low basal activities (wild-type), a half had low-level constitutive activities $\left(\mathrm{icl}^{\mathrm{c}} \mathrm{Al}\right.$ or $\mathrm{icl}^{\mathrm{c} B l}$ ) while the remaining quarter had high-level constitutive activity. One of the high-level strains (QT31) was isolated and shown to be the double mutant $i_{c l}{ }^{\mathrm{c}} A 1 ;{ }_{i c l}{ }^{\mathrm{B}} B 1$ by a further cross to wild-type, in which the same three classes were observed in similar ratios. In the cross between $i c c^{\mathbf{c}} A 4$ and $\mathrm{icl}^{\mathrm{c}} \mathrm{Bl}$ four classes of progeny could be distinguished using the qualitative test for constitutive isocitrate lyase activity. These presumably correspond to the four genotypes $i c c^{\mathrm{c}} \mathrm{A}^{+} ; \mathrm{icl}^{\mathrm{c}} \mathrm{B}^{+}$and $i \mathrm{clc} \mathrm{A}^{+}$; $i c l c B l$ and $i c l^{c} A 4 ; i c l^{c} B^{+}$and $i c l^{c} A 4 ; i c l^{c} B 1$ which produce enzyme activities in sucrose grown mycelium in the ranges 0.1 to 0.3 and 3.0 to 6.0 and 7.0 to 10.0 and 12.0 to 15.0 units, respectively. One high-level double mutant strain (QZ64) was studied further.

The $i c l^{\mathbf{c}} A$ and $i c l^{c} B$ mutations thus show a remarkable synergism when combined (Tables 3 and 5). The interaction is clearly multiplicative rather than additive, which suggests that the loci act in a sequential manner in the regulation of isocitrate lyase formation rather than affecting functions which act in parallel. 
Table 5. Isocitrate lyase activities in constitutive strains after growth on various carbon sources

Strains were grown for the times indicated on carbon sources in liquid culture containing $0.2 \mathrm{M}$ phosphate buffer pH 6.5 (except in the case of sucrose where the additional buffer was omitted). Standard methods were used to prepare cell-free extracts and to measure isocitrate lyase specific activities [ $\mu \mathrm{mol}$ glyoxylate formed $\left.\mathbf{h}^{-1}(\mathrm{mg} \text { protein })^{-1}\right]$.

Carbon source for growth and incubation time

\begin{tabular}{|c|c|c|c|c|c|c|c|}
\hline Strain & $\begin{array}{c}\text { Sucrose } \\
(0.02 \mathrm{M}) \\
18 \mathrm{~h}\end{array}$ & $\begin{array}{c}\text { D-Galactose } \\
(0.02 \mathrm{M}) \\
33 \mathrm{~h}\end{array}$ & $\begin{array}{c}\text { Glycerol } \\
(0.04 \mathrm{M}) \\
18 \mathrm{~h}\end{array}$ & $\begin{array}{c}\text { L-Glutamate } \\
(0.04 \mathrm{M}) \\
39 \mathrm{~h}\end{array}$ & $\begin{array}{c}\text { L-Proline } \\
(0.04 \mathrm{M}) \\
33 \mathrm{~h}\end{array}$ & $\begin{array}{c}\text { Acetate } \\
\left(0 \cdot 10_{\mathrm{M}}\right) \\
24 \mathrm{~h}\end{array}$ & $\begin{array}{c}\text { Sucrose }(0.02 \mathrm{M})+ \\
\text { acetate }(0.10 \mathrm{M}) \\
18 \mathrm{~h}\end{array}$ \\
\hline $\begin{array}{l}\text { R21 (wild-type) } \\
\text { SVA33 icle } A 1 \\
2301 \mathrm{icl}^{\mathrm{c}} A 4 \\
\text { M279 } \mathrm{ic} l^{\mathrm{c} B I} \\
\text { OT31 }\end{array}$ & $\begin{array}{l}0 \cdot 1 \\
0.9 \\
6 \cdot 6 \\
0 \cdot 7\end{array}$ & $\begin{array}{l}0 \cdot 1 \\
4 \cdot 9 \\
5 \cdot 8 \\
1 \cdot 5\end{array}$ & $\begin{array}{l}0 \cdot 1 \\
5 \cdot 2 \\
7 \cdot 6 \\
2 \cdot 8\end{array}$ & $\begin{array}{r}0.3 \\
2.9 \\
11 \cdot 2 \\
4.6\end{array}$ & $\begin{array}{l}0 \cdot 8 \\
7 \cdot 9 \\
7 \cdot 5 \\
3 \cdot 1\end{array}$ & $\begin{array}{l}43 \cdot 5 \\
49 \cdot 5 \\
32 \cdot 0 \\
45 \cdot 8\end{array}$ & $\begin{array}{l}12 \cdot 9 \\
19 \cdot 8 \\
21 \cdot 0 \\
19 \cdot 5\end{array}$ \\
\hline $\begin{array}{l}{ }_{\mathrm{icl}} A I ; i c l^{\mathrm{c}} B I \\
\mathrm{QZ} 64\end{array}$ & 7.6 & 8.4 & $9 \cdot 1$ & $29 \cdot 8$ & $10 \cdot 4$ & 46.5 & $18 \cdot 3$ \\
\hline$i c l^{c} A 4 ; i c l^{2} B 1$ & $14 \cdot 7$ & $13 \cdot 3$ & $15 \cdot 3$ & $128 \cdot 0$ & $10 \cdot 5$ & $46 \cdot 7$ & 33.9 \\
\hline
\end{tabular}

Effects of carbon source in growth on isocitrate lyase formation. While it was evident that the very low basal isocitrate lyase activities in wild-type mycelium were subject to some derepression on certain carbon sources, the effect was very small compared with that of growth in the presence of acetate (Table 5). The $i c l^{\mathbf{c}} A$ and $i c l^{\mathbf{c}} B$ strains showed a similar response to derepression as did the wild-type, and only small effects on enzyme formation during growth on a mixture of sucrose and acetate. The double mutant strains $i \mathrm{clc} A ; i c l c B$ showed a synergistic interaction in each situation. The very high enzyme activities occurring during growth on glutamate were particularly striking, though the reason for these high activities and the much smaller effect during growth on proline are obscure. It is notable that the constitutive strains were not hyper-induced when grown in the presence of acetate, and that the strong synergistic interaction between $i^{c} l^{c} A$ and $i c l c B$ did not occur during growth on sucrose with acetate. We conclude that the $i^{c} l^{c} A$ and $i c l c B$ mutations affect the induction of isocitrate lyase and not the weak carbon catabolite repression.

Expression of the isocitrate lyase constitutive mutations in diploid strains. A number of diploid strains were constructed between suitable $i c l c A$ or $i c l c B$ recombinants and wild-type strains to produce a series of configurations of mutant or wild-type alleles at the two loci (Table 3). Again, the enzyme activities found in the diploid strains grown on sucrose in liquid culture clearly showed that the $i c l c A 1, A 2$ and $A 4$ mutations are recessive to their wild-type allele. The $i^{\prime}{ }^{\mathbf{c}} B 1$ mutation showed incomplete dominance in the heterozygous diploid with a marked gene dosage relationship. This gene dosage response was also found for the $i c l^{c} B 1$ mutation in diploids homozygous for the $i c l^{c} A I$ mutation, and the double mutant homozygous diploid strain showed the same multiplicative synergism noted in the double mutant haploid strains.

$\mathrm{icl}^{\mathrm{c}}$ constitutive mutations do not affect the formation of malate synthase or of acetyl-CoA synthase. It seemed unlikely that the isocitrate lyase constitutive mutations $\left(i c^{c}\right)$ would affect the formation of malate synthase, since they alone did not replace the $C_{4}$ organic acid requirements resulting from the pyruvate carboxylase lesion ( $p y c A)$, which would have required the presence of both enzymes of the glyoxylate cycle. No constitutive formation of malate synthase was detected in the original revertant strain pycA3; acuM 301 r25 (Table 6), nor in separate $i c l^{c} A$ and $i c l^{c} B$ mutant strains. A low constitutive malate synthase activity might have been overlooked in the $i c l^{c} A$ or $i c l c B$ mutants due to the relative insensitivity of the assay. However, this would not have been the case in the $i c c^{c} A ; i c l c B$ double 


\section{Table 6. Malate synthase and acetyl-CoA synthase activities in isocitrate lyase constitutive strains}

Mycelia of the strains shown were grown on acetate $(0.10 \mathrm{M})$ for $24 \mathrm{~h}$, or on sucrose $(0.02 \mathrm{M})$ with acetate $(0.10 \mathrm{M})$ for $18 \mathrm{~h}$, or on sucrose $(0.02 \mathrm{M})$ for $18 \mathrm{~h}$. Procedures for enzyme assays are given in Methods. Specific activities are expressed as $\mu \mathrm{mol}$ product formed $\mathbf{h}^{-1}$ (mg protein) $^{-1}$.

\begin{tabular}{|c|c|c|c|c|}
\hline \multirow[b]{2}{*}{ Strain } & \multirow[b]{2}{*}{ Carbon source for growth } & \multicolumn{3}{|c|}{ Specific activities } \\
\hline & & $\begin{array}{c}\text { Isocitrate } \\
\text { lyase }\end{array}$ & $\begin{array}{c}\text { Malate } \\
\text { synthase }\end{array}$ & $\begin{array}{c}\text { Acetyl-CoA } \\
\text { synthase }\end{array}$ \\
\hline R21 (wild-type) & Acetate & - & $6 \cdot 2$ & $2 \cdot 74$ \\
\hline R21 (wild-type) & $\begin{array}{l}\text { Sucrose }+ \text { acetate } \\
\text { Sucrose + acetate } \\
\text { Sucrose + acetate }\end{array}$ & $\begin{array}{l}\overline{8 \cdot 2^{*}} \\
7 \cdot 1^{*}\end{array}$ & $\begin{array}{l}\overrightarrow{4 \cdot 0^{*}} \\
2 \cdot 5^{*}\end{array}$ & $\begin{array}{c}0.55 \\
- \\
-\end{array}$ \\
\hline R21 (wild-type) & $\begin{array}{l}\text { Sucrose } \\
\text { Sucrose }\end{array}$ & $\begin{array}{l}0.3^{*} \\
0.1\end{array}$ & $\begin{array}{l}0 * \\
0.1\end{array}$ & $\overline{0.13}$ \\
\hline pyc $A 3 ;$ acuM301; su+; icl c $^{\circ} A l$ & Sucrose & $5 \cdot 0^{*}$ & $0^{*}$ & - \\
\hline SVA33 $i c l^{\circ} A I$ & $\begin{array}{l}\text { Sucrose } \\
\text { Sucrose }\end{array}$ & $\frac{2 \cdot 0^{*}}{-}$ & $\begin{array}{l}0^{*} \\
0\end{array}$ & $\overline{0.19}$ \\
\hline M279 icl'B1 & Sucrose & $3 \cdot 2$ & 0.3 & 0.16 \\
\hline QT31 icl' $A 1 ; i c l^{\circ} B 1$ & Sucrose & $10 \cdot 2$ & $0 \cdot 1$ & $0 \cdot 11$ \\
\hline
\end{tabular}

* These assays were done on the same cell-free extracts.

mutant strain had these mutations affected malate synthase formation in the same way as isocitrate lyase.

The structural genes for acetyl-CoA synthase $(a c u A)$ and isocitrate lyase $(a c u D)$ are closely linked in A. nidulans (Armitt et al., 1976), which could be significant for their regulation, since each functions at a branch point in the metabolic pathway for acetate utilization. However, the $i c l^{c}$ mutations had no effect on the formation of acetyl-CoA synthase in sucrose-grown mycelium (Table 6).

\section{Reversion experiments with strain pycA3; iclc $A 1 ; i c l^{\circ} B 1$}

The double mutant isocitrate lyase constitutive strain $i \mathrm{cl}^{\mathbf{c}} A 1 ; i \mathrm{cl} \mathbf{c} B 1$ shows a high isocitrate lyase activity when growing on sucrose (Table 5). If such a strain also contained a lesion in pyruvate carboxylase ( $p y c A$ ) the resulting $\mathrm{C}_{4}$ requirement could possibly be repaired by completion of the glyoxylate cycle in mutants forming malate synthase constitutively.


$i c l^{\circ} B I$ ) with $p y c A 3$. The strain QW4-3 does not grow on sucrose medium although it contains both $\mathrm{icl}^{\mathbf{c}}$ mutations and has the potential to form high constitutive levels of isocitrate lyase. This result demonstrates again that the pyruvate carboxylase lesion $(p y c A)$ is not repaired by constitutivity for isocitrate lyase and that a complete glyoxylate cycle is required to effect net $\mathrm{C}_{4}$ synthesis.

Conidia of strain QW4-3 were treated with $N$-methyl- $N$ '-nitro- $N$-nitrosoguanidine and plated on sucrose medium. Revertants were cloned and then assayed for malate synthase activity after growth in liquid media with sucrose as the sole carbon source. Of 25 revertants tested, 9 (called mas) had significant levels of malate synthase up to the activity found in fully induced wild-type (Table 7). None of these strains had regained pyruvate carboxylase activity. The revertants were tested for several other enzymes with a possible $C_{3} \rightarrow C_{4}$ carboxylating function (Table 7). Strain mas 78 had a low constitutive level of phosphoenolpyruvate (PEP) carboxykinase and of those tested for malic enzyme both mas 78 and mas 92 had a high activity. The revertants were also tested for PEP carboxylase activity which has been reported to be present in $A$. nidulans grown in glucose-limited continuous 
Table 7. Enzyme activities in revertants of pycA3; icl ${ }^{\mathrm{C}} \mathrm{Al} ; \mathrm{icl}^{\mathrm{c}} \mathrm{B1}$

Strains were grown on acetate $(0.10 \mathrm{M})$ for $24 \mathrm{~h}$ or on sucrose $(0.02 \mathrm{M})$ for $18 \mathrm{~h}$. The enzymes were assayed on different occasions following the procedures given in Methods. Specific activities are expressed as $\mu \mathrm{mol}$ product formed $\mathrm{h}^{-1}$ (mg protein) ${ }^{-1}$.

\begin{tabular}{|c|c|c|c|c|c|}
\hline \multirow[b]{2}{*}{ Strain } & \multirow[b]{2}{*}{$\begin{array}{l}\text { Carbon source } \\
\text { for growth }\end{array}$} & \multicolumn{4}{|c|}{ Specific activities } \\
\hline & & $\begin{array}{l}\text { Isocitrate } \\
\text { lyase }\end{array}$ & $\begin{array}{c}\text { Malate } \\
\text { synthase }\end{array}$ & $\begin{array}{c}\text { PEP } \\
\text { carboxykinase }\end{array}$ & $\begin{array}{l}\text { Malic } \\
\text { enzyme }\end{array}$ \\
\hline $\begin{array}{l}\text { Controls: } \\
\text { R21 (wild-type) }\end{array}$ & $\begin{array}{l}\text { Acetate } \\
\text { Sucrose }\end{array}$ & $\begin{array}{r}39.0 \\
0.1\end{array}$ & $\begin{array}{l}4 \cdot 5 \\
0 \cdot 4\end{array}$ & $\begin{array}{r}34 \cdot 0 \\
1.0\end{array}$ & $\begin{array}{l}2 \cdot 4 \\
0.3\end{array}$ \\
\hline $\begin{array}{c}\text { Revertants: } \\
\text { mas } 63 \\
\text { mas } 69 \\
\text { mas } 75 \\
\text { mas } 78 \\
\text { mas } 89 \\
\text { mas } 92 \\
\text { mas } 93 \\
\text { mas } 95 \\
\text { mas } 101\end{array}$ & $\begin{array}{l}\text { Sucrose } \\
\text { Sucrose } \\
\text { Sucrose } \\
\text { Sucrose } \\
\text { Sucrose } \\
\text { Sucrose } \\
\text { Sucrose } \\
\text { Sucrose } \\
\text { Sucrose }\end{array}$ & $\begin{array}{r}17.4 \\
0.9 \\
11.2 \\
18.3 \\
10.3 \\
7.7 \\
10.7 \\
5.9 \\
6.2\end{array}$ & $\begin{array}{l}3.1 \\
1.6 \\
2.4 \\
2.6 \\
0.9 \\
2.3 \\
3.7 \\
0.9 \\
4.0\end{array}$ & $\begin{array}{l}0.2 \\
0.6 \\
2.4 \\
0.2 \\
0.3 \\
0.6 \\
0.2 \\
0.2\end{array}$ & $\begin{array}{l}Z \\
Z \\
1.5 \\
0.6 \\
1.6 \\
- \\
0 \\
0.7\end{array}$ \\
\hline
\end{tabular}

culture (Bushell \& Ball, 1974). However, no activity was detected in the revertants or in wild-type (R21).

Revertant strain mas 78 was initially chosen for genetic analysis and crossed to wild-type (R21). As expected from the enzyme results the pycA marker segregated in the cross, and among the progeny growing on sucrose we found low and high levels of constitutive malate synthase. However, another factor was found which caused slow growth on both sucrose and on acetate media. Analysis of mas 78 through sexual crosses was abandoned because the number of markers present gave rise to a large number of progeny classes which would have been time-consuming to prove through test crosses. (The complete analysis of the isocitrate lyase constitutive strain $p y c A 3 ; a c u M 301 ; \mathrm{su}^{+} ; i \mathrm{cl} \mathrm{C}^{\mathrm{C}} \mathrm{Al}$ required a series of 30 test crosses.) In an attempt to overcome this problem we decided to analyse several of the revertants through haploidization of diploids constructed from the mas strains and a tester strain (FGSC 480) which has at least one genetic marker on each chromosome. Since the chromosomal locations of $p y c A, i c c^{c} A$ and $i c^{\mathrm{c} B} B$ were known, the status of these markers in haploid segregants from the diploid could be determined readily. The genotype of the diploid is shown in Fig. 1.

It now seems likely that the QW4-3 revertants, like the original $p y c A$ revertants, carry suppressor mutations which act by bypassing the pyruvate carboxylase lesion, although it is not known if the additional $s u^{+}$mutations are allelic. The high level of malate synthase, and PEP carboxykinase in mas 78 and 92, may be a consequence of the poor growth rate and the metabolic disturbances caused by the presence of the $p y c A, i c l^{\mathrm{e}} A,{ }_{i c l} \mathrm{~B}$ and $s u^{+}$ mutations. However, it remains possible that these effects occur in conjunction with other mutations which alone produce a low level of constitutive malate synthase not detectable by our assay procedure. Indeed, a similar situation occurred with the original $p y c A$ revertants carrying the $i^{\mathrm{C}} \boldsymbol{A}$ mutations. The high constitutive isocitrate lyase activity in the revertants diminished considerably when the $i^{\mathbf{c}} \mathbf{c}$ mutations were crossed into an otherwise wild-type genetic background (Table 1). These low isocitrate lyase activities, about $4 \%$ of the maximum, were readily detected by the assay which is sensitive to $0.1 \%$ of the maximum value. However, the malate synthase assay was unreliable below about $20 \%$ of the maximum value due to high endogenous readings in the substrate-free blank.

We would very much like to know how the $p y c A 3 s u^{+}$mutations act to repair the pyruvate carboxylase lesion. 
I

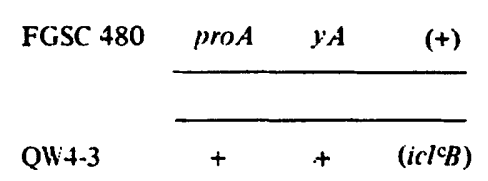

II



III
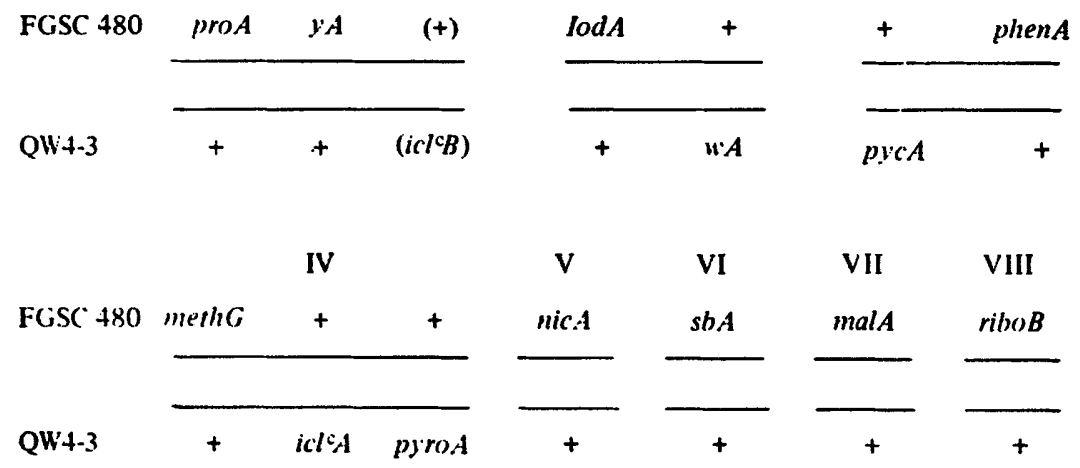

Fig. 1. Genotype of diploids constructed between the tester strain FGSC 480 and revertants of QW4-3. Linkage groups are indicated by Roman numerals. Markers shown in parentheses have not been mapped within linkage groups. Allele symbols are described in the text.

\section{Can loss mutations be demonstrated at the icl $\mathrm{B}$ locus?}

The ${ }^{i} c^{\mathfrak{c}} B 1$ mutation is incompletely dominant (Table 3 ), suggesting that it codes for an altered gene product which has a positive role in the regulation of the $a c u D$ locus and the induction of isocitrate lyase. If this hypothesis is correct the strong prediction follows that recessive loss mutations at the $\mathrm{icl}^{\mathrm{c} B} \mathrm{~B}$ locus should be uninducible and thus unable to grow on acetate since isocitrate lyase is required for acetate utilization. We sought to test this prediction by selecting acetate non-utilizing ( $\mathrm{acu}$ ) mutants in a constitutive strain carrying the $\mathrm{icl}^{\mathrm{c}} \mathrm{Bl}$ allele and screening the mutants for the concomitant loss of constitutive isocitrate lyase.

A suspension of conidia of an $\mathrm{icl}^{\mathbf{C}} \mathrm{BI}$ strain (M279) was treated with ultraviolet light and acu mutants were isolated following filtration enrichment. Among 280 acu mutants, 25 lacked constitutive isocitrate lyase activity in the qualitative test done on sucrose-grown mycelium. To distinguish between the possibilities that the non-constitutive, acetate nonutilizing strains might contain mutations in the structural gene for isocitrate lyase (acuD) rather than loss of the $i^{c}{ }^{\mathbf{c}} B$ function, all 25 strains were crossed to wild-type (R153). From each cross 20 progeny were screened for constitutive formation of isocitrate lyase using the qualitative test on sucrose-grown mycelium. In each cross the $i c l^{\mathbf{c}} B I$ marker segregated among the progeny showing that none of the 25 acetate non-utilizing strains arose by loss of the $i c l^{\mathbf{c}} B 1$ function. This strongly indicates that the $i c l^{\mathbf{c}} B$ locus does not play a primary role in the induction process. It should be stressed, however, that no leaky acu mutants were retained in the experiment due to the use of the filtration enrichment technique, and loss mutations at the $i c l^{c} B$ locus would have been isolated only if they resulted in total loss of growth on acetate. The significance of this result for the interpretation of the role of the $\mathrm{icl}^{\mathrm{C}} \mathrm{B}$ locus is considered further in the Discussion.

\section{Complementation analysis of the acetate non-utilizing (acu) mutants derived from icl ${ }^{\mathrm{B} I}$}

None of the 25 mutant strains described above had lost the $i c l c B 1$ mutation and the potential to form isocitrate lyase constitutively. It is therefore likely that the mutants failed to express this potential due to mutations in the structural gene $a c u D$ for the enzyme protein. Strains with presumptive new $a c u D$ mutations were provisionally identified by the absence of isocitrate lyase on induction by growth on sucrose in the presence of acetate. Three mutants (403, 406 and 419) had low enzyme activities under these conditions and were discarded. Another mutant (405) was also discarded because it conidiated poorly. 


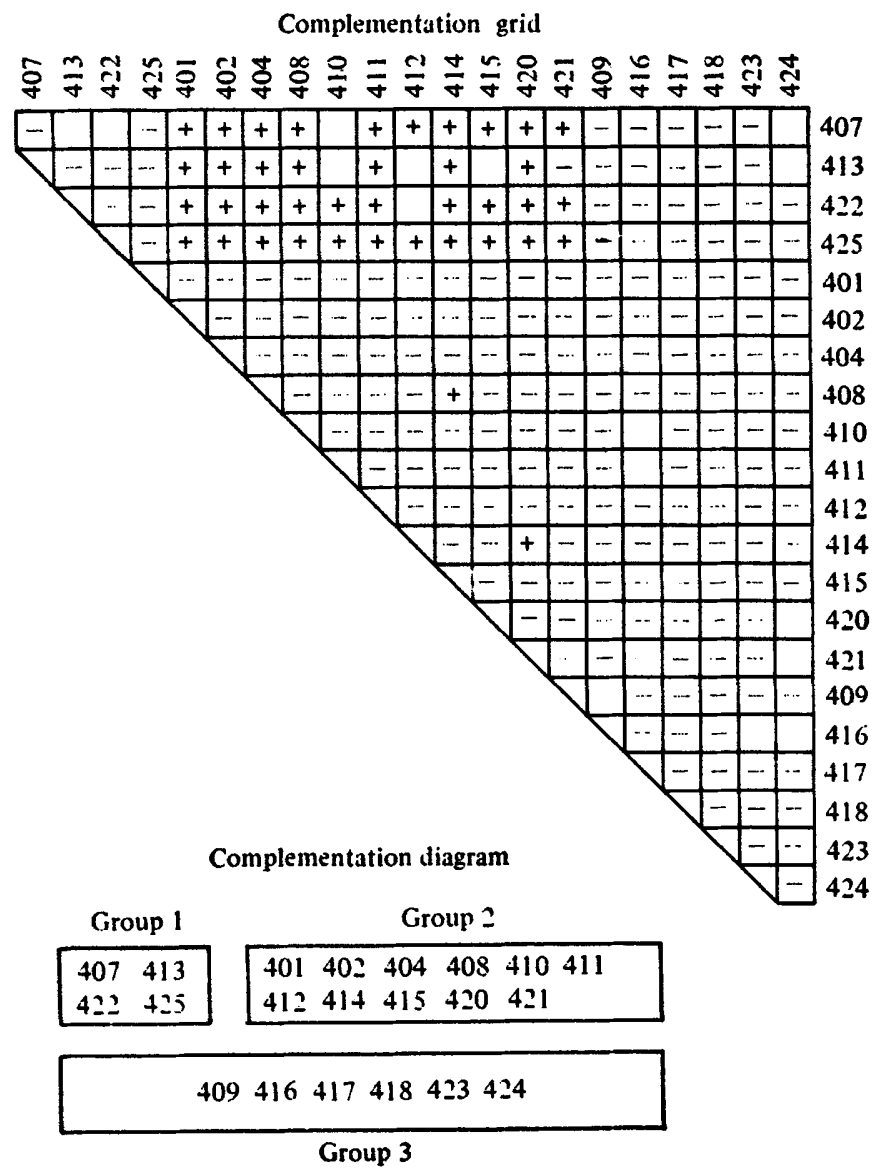

Fig. 2. Complementation analysis of isocitrate lyaseless mutants at the acuD locus. Acetate nonutilizing acu mutants isolated in the $i c l^{C} B I$ strain and lacking isocitrate lyase activity were subjected to complementation analysis in heterokaryons. The results are summarized in a complementation diagram which shows the mutants falling into three groups.

Since failure to induce isocitrate lyase might occur by mutation at loci other than the known structural gene locus $a c u D$, we considered it worthwhile to analyse the remaining 21 acetate non-utilizing acu mutants through complementation. Each of the mutants had already been crossed to wild-type and progeny with suitable combinations of conidial colour markers and of nutritional markers to facilitate the construction of heterokaryons were available, although some would carry the $i c l \mathbf{c} B 1$ mutation masked by the acu mutation. Heterokaryons were synthesized on sucrose media from pairwise combinations of mutants and tested for their growth on acetate (Fig. 2). The acu mutants could be assigned to three groups $-1,2$ and 3. Complementation was observed between mutants in groups 1 and 2, but rarely within the groups, while mutants in group 3 did not complement any other. Mutant 424, which does not complement, was heat-sensitive for growth at $37^{\circ} \mathrm{C}$ on acetate medium but grew as well as wild-type at $25^{\circ} \mathrm{C}$. Furthermore, isocitrate lyase activity from this strain was more sensitive to heat inactivation at $37^{\circ} \mathrm{C}$ than was the enzyme from wildtype. Mutant 424 (group 3) and a representative mutant from group 1 (407) and group 2 (401) were crossed with a strain carrying an $a c u A$ marker known to be tightly linked to the $a c u D$ locus (Armitt et al., 1976). The results indicated tight linkage ( $<2 \%$ recombination) between the new acu mutations and acuA. Mutants lacking isocitrate lyase had been 
isolated previously (Armitt et al., 1976) and it was of interest to determine if the complementation properties observed with the new mutants were found there also. Mutants representing each of the three complementation groups were used to construct heterokaryons with each of the original $a c u D$ mutants and the heterokaryons were tested for growth on acetate. The earlier mutants also fell into the same complementation groups. Taken together the results provide strong evidence for a single structural gene locus coding for isocitrate lyase protein. However, the complementation results indicate that the locus contains two genetically distinct regions.

\section{DISCUSSION}

The formation of isocitrate lyase and malate synthase in Aspergillus nidulans was found roughly co-ordinate in response to acetate induction, and deficient in mutants lacking acetyl-CoA synthase, though normal for enzymes later in the pathway of acetate metabolism (Armitt et al., 1976). Acetamidase is induced by a similar mechanism of acetate metabolism (Hynes, 1977). Moreover, cre mutants partially resistant to carbon catabolite repression are partially derepressed for acetamidase, isocitrate lyase and acetyl-CoA synthase, possibly with regulation of the first two enzymes by acetyl-CoA concentrations set by acetyl-CoA synthase (Kelly \& Hynes, 1977).

The low-level $\mathrm{icl}^{\mathbf{c}}$ constitutive mutations reported here are unlinked to the isocitrate lyase structural gene locus (linkage group V) and did not affect the formation of malate synthase (structural gene in linkage group I) or acetyl-CoA synthase, the structural gene for which is closely linked to that for isocitrate lyase (Armitt et al., 1976). The $\mathrm{icl}^{\mathbf{c}}$ mutations are thus distinct from the cre catabolite derepression mutations which affect both isocitrate lyase and acetyl-CoA synthase activities, and, indeed, produce a similar increase in activities of these enzymes during growth on sucrose alone (Kelly \& Hynes, 1977). The $\mathrm{creA}^{\mathrm{A}}$ and $\mathrm{icl}^{\mathrm{C}} \mathrm{A}$ loci are in linkage group I, but $c r e B$ and $c r e C$ (group II) and $i^{\prime} l^{\mathbf{c}} B$ (group IV) are unlinked. Thus, both general and specific regulatory effects have been observed on two tightly linked structural genes. Similar dual regulation of clusters of closely linked functionally related structural genes is common in $\boldsymbol{A}$. nidulans (for review, see Pateman \& Kinghorn, 1977), as are regulated gene clusters in Neurospora crassa and other fungi (Giles, 1978).

The finding that the $\mathrm{icl}^{\mathbf{c}}$ mutations did not affect the formation of malate synthase was reinforced by their inability to allow growth of the pyruvate carboxylaseless ( $p y c A)$ mutant when combined in a double mutant strain. A complete genetic analysis of one isocitrate lyase constitutive $p y c A$ revertant ( $\mathrm{r} 25)$ showed that two mutations - $s u^{+}$, a pyruvate carboxylase suppressor mutation, and $\mathrm{icl}^{\mathrm{c}} \mathrm{Al}$ - were required to suppress the PycA phenotype when conidia were plated to give isolated colonies (conditions similar to those used in selecting the revertants) or when inoculated into liquid growth media. The $i c l^{\mathrm{c}} A I$ mutation only affects growth when combined with $p y c A$ and $s u^{+}$mutations, whereas the $s u^{+}$mutation isolated in an otherwise wild-type genome $\left(p y c A^{+} ; i c l^{c} A^{+}\right)$has a perceptible deleterious effect on growth, reducing the density of mycelium and conidiation of colonies. The procedure used in selecting $p y c A$ revertants and subsequent screening for isocitrate lyase activity therefore recovered double mutant strains in which repair of the pyruvate carboxylase lesion was by a metabolic bypass which was not the glyoxylate cycle. The same result was found for two of the three other isocitrate lyase constitutive pycA revertants. The nature of the metabolic bypass of the pyruvate carboxylase lesion released by the $s u^{+}$mutations and generating a supply of $\mathbf{C}_{\mathbf{4}}$ tricarboxylic acid cycle intermediates is not known. Two possible mechanisms acting through malic enzyme (pyruvate $\rightarrow$ malate) or PEP carboxykinase (PEP $\rightarrow$ oxaloacetate) are unlikely on the basis of genetic results. Thus, the $s u^{+}$ mutations are effective in a pyruvate carboxylaseless (pycA) strain which also lacks malic enzyme activity due to acuM mutations (revertant $\mathrm{r} 25$ ) and also in other strains which lack PEP carboxykinase (unpublished results). The physiological role of the iclc mutations 
enabling growth of $s u^{+} ; p y c A$ strains when conidia are isolated on solid media or inoculated into liquid culture is also not known. One interpretation is that under these conditions the alternative pathway of $\mathrm{C}_{4}$ synthesis required the presence of an enzyme controlled by the $\mathrm{icl}^{\mathrm{c}}$ genes, and the effect on isocitrate lyase was secondary. However, one constitutive mutant $i c l^{c} A 4$ was recovered by total isolation when no selection was applied for the $p y c A$ bypass. We thus conclude that the $i \mathrm{cl}^{\mathbf{c}}$ genes are primarily involved in the genetic regulation of the isocitrate lyase structural gene. We cannot, however, define the function of isocitrate lyase in relation to suppression of the pyruvic carboxylase lesion (pycA).

The four isocitrate lyase constitutive mutations $(\mathrm{icl} / \mathrm{c})$ extracted from the pyruvate carboxylaseless $(p y c A)$ revertants and the fifth obtained by total isolation without selection identified two unlinked loci $i^{c}{ }^{\mathbf{c}} A$ (linkage group I) and $i_{c} \mathbf{c} B$ (group IV) affecting the formation of isocitrate lyase activity. The mutant genes showed a strong synergistic (multiplicative) interaction in double mutant strains and this, together with the dominance relationships, suggests a model for the genetic control of the isocitrate lyase structural gene $(a c u D$, group $\mathrm{V})$. In this model the $i c l^{\mathbf{c}} A$ gene product has a negative repressing function and the $i c l^{\mathbf{c}} B$ gene product a positive role for induction. Thus, the $i^{c} l^{\mathbf{c} B}$ gene product is required for enzyme induction while, in the absence of the inducer, it is inactivated or otherwise prevented from functioning by the $i^{c}{ }^{c} A$ gene product. In the presence of the inducer, inactivation of the $i^{c}{ }^{\mathbf{c}} B$ gene product does not occur and enzyme is formed. The structural gene $a c u D$ for isocitrate lyase is therefore under negative control in the absence of inducer and positive control when inducer is present. According to this model the $i c l \mathbf{c} B$ mutant has an altered regulatory protein which partly functions in 'switching on' the structural gene in the absence of exogenous inducer, and is not antagonized by the repressor. The $\mathrm{icl}^{\mathrm{c}} \boldsymbol{A}$ mutants are deficient in repressor. This interpretation is formally identical to the model proposed by Bartnik \& Weglenski (1974) for the regulation of ornithine aminotransferase in $A$. nidulans. Clearly, other genetic elements are involved in isocitrate lyase regulation since the highest constitutive enzyme activities found in a double mutant $\left(i \mathrm{cl} \mathrm{c}^{\mathrm{c}} \mathrm{A4} ; \mathrm{icl} \mathrm{c} B \mathrm{l}\right)$ were only one-third of the fully induced activity.

An alternative interpretation of the $i c l^{c}$ mutants is that they are endogenously induced by the accumulation of metabolic intermediates resulting from unidentified enzyme deficiencies. The striking interactions found between the $i^{c} l^{c}$ mutations, the pyruvate carboxylaseless ( $p y c A$ ) mutant, the $p y c A$ suppressor mutation $s u^{+}$and the malic enzyme mutation $a c u M$ in affecting isocitrate lyase activities lends support to such a belief.

This work was supported by the Science Research Council (grant B/RG/1667-9). We are grateful to Dr M. A. Payton for helpful discussions and especially to Mr J. A. Mackley for his skilled and enthusiastic technical support.

\section{REFERENCES}

Alderson, T. \& Hartley, M. J. (1969). Specificity for spontaneous and induced forward mutation at several gene loci in Aspergillus nidulans. Mutation Research 8, 255-264.

Armitt, S., McCullough, W. \& Roberts, C. F. (1976). Analysis of acetate non-utilizing (acu) mutants in Aspergillus nidulans. Journal of General Microbiology 92, 263-282.

Bartnik, E. \& Weglenski, P. (1974). Regulation of arginine catabolism in Aspergillus nidulans. Nature, London 250, 590-592.

Brice, C. B. \& KornberG, H. L. (1968). Genetic control of isocitrate lyase activity in Escherichia coli. Journal of Bacteriology 96, 2185-2186.
Bushell, M. E. \& Bull, A. T. (1974). Anaplerotic carbon dioxide fixation in steady state and nonsteady state fungal cultures. Proceedings of the Society for General Microbiology 1, 69.

Clutrerbuck, A. J. (1974). Aspergillus nidulans. In Handbook of Genetics, vol. 1, pp. 447-510. Edited by R. C. King. New York: Plenum Press. Falmange, P., Vanderwinkel, E. \& Wiame, J. M. (1965). Mise en évidence de deux malate synthases chez Escherichia coli. Biochimica et biophysica acta 99, 246-258.

Glles, N. H. (1978). The organisation, function, and evolution of gene clusters in eukaryotes. American Naturalist 112, 641-657. 
HYNES, M. J. (1977). Induction of the acetamidase of Aspergillus nidulans by acetate metabolism. Journal of Bacteriology 131, 770-775.

KELLY, J. M. \& HYNES, M. J. (1977). Increased and decreased sensitivity to carbon catabolite repression of enzymes of acetate metabolism in mutants of Aspergillus nidulans. Molecular and General Genetics 156, 87-92.

KornberG, H. L. (1966a). Anaplerotic sequences and their role in metabolism. Essays in Biochemistry 2, 1-31.

KornberG, H. L. $(1966 b)$. The role and control of the glyoxylate cycle in Escherichia coli. Biochemical Journal 99, 1-11.

Miller, A. L. \& Atkinson, D. E. (1972). Response of yeast pyruvate carboxylase to the adenylate energy charge and other regulatory parameters. Archives of Biochemistry and Biophysics 152, 531538.

Pateman, J. A. \& KInghorn, J. R. (1977). Genetic regulation of nitrogen metabolism. In Genetics and Physiology of Aspergillus, pp. 203-241. Edited by J. E. Smith \& J. A. Pateman. London \& New York: Academic Press.

Payton, M., McCullough, W. \& Roberts, C. F.
(1976). Agar as a carbon source and its effect upon the utilization of other carbon sources by acetate non-utilizing ( $a c u$ ) mutants of Aspergillus nidulans. Journal of General Microbiology 94, 228233.

Pontecorvo, G., Roper, J. A., Hemmons, L. J., Macdonald, K. D. \& Bufton, A. W. J. (1953). The genetics of Aspergillus nidulans. Advances in Genetics 5, 141-238.

SkINNER, V. M. \& ARMTTT, S. (1972). Mutants of Aspergillus nidulans lacking pyruvate carboxylase. FEBS Letters 20, 16-18.

Syrett, P. J., MerretT, M. J. \& Bocks, S. H. (1963). Enzymes of the glyoxylate cycle in Chlorella vulgaris. Journal of Experimental Botany 14, 249264.

VANDERWinkel, E., Liard, P., RAMOS, F. \& Wiame, J. M. (1963). Genetic control of the regulation of isocitrate lyase and malate synthase in Escherichia coli K12. Biochemical and Biophysical Research Communications 12, 157-162.

WALDRON, C. \& ROBERTS, C. F. (1974). Coldsensitive mutants in Aspergillus nidulans. I. Isolation and general characterisation. Molecular and General Genetics 134, 99-113. 